\title{
TANGGUNG GUGAT BII TERHADAP HILANGNYA BARANG DALAM SAFE DEPOSIT BOX
}

\author{
Metya Janastu \\ Fakultas Hukum, Universitas Airlangga \\ e-mail: metyajanastu@yahoo.com
}

\begin{abstract}
ABSTRAK
Safe Deposit Box (SDB) sebagai salah satu bentuk jasa perbankan untuk menyediakan tempat penyimpanan barang dan surat berharga milik nasabah yang telah dijamin dalam peraturan perundangundangan di bidang perbankan. Perjanjian safe deposit box berdasarkan pada perikatan sewa menyewa. Bank memperoleh imbal balik berupa biaya jasa dalam menunaikan kewajibannya dalam menyimpan barang dan surat berharga tersebut dengan itikad baik termasuk bertanggungjawab atas hilangnya obyek safe deposit box akibat pembobolan bank karena bank dianggap lalai menunaikan kewajibannya sesuai perjanjian jasa safe deposit box. Unsur kelalaian bank harus dapat dibuktikan dalam penyelesaian kasus dengan merujuk pada ketentuan peraturan perundang-undangan di bidang perbankan dan perlindungan konsumen. Penelitian normatif ini akan mengkaji mengenai tanggung gugat bank khususnya BII atas hilangnya benda menjadi obyek safe deposit box. Hasil dari penelitian ini adalah pentingnya asas itikad baik bank sebagai pelaku usaha dalam pertanggungjawaban kelalaian bank serta pentingnya aspek kehatihatian nasabah dalam pengikatan perjanjian safe deposit box.
\end{abstract}

Kata Kunci: bank; safe deposit box; tanggung gugat

\section{ABSTRACT}

Safe Deposit Box (SDB) as a form of banking services to provide a storage area for customers' goods and securities that have been guaranteed by the laws and regulations in the banking sector. The safe deposit box agreement is based on a lease agreement. Bank receives service fees when fulfilling its obligations to storing these goods and secutirites with a good faith, including being responsible for the loss of objects due to breaking because the bank is deemed negligent in fulfilling its obligations according to the safe deposit box agreement. Negligence factor must be proven in case settlement by referring to regulations in banking and consumer protection. This normative research will examine the accountability of banks, especially BII, for the loss of objects in safe deposit boxes. The results of this study are the importance of the principle of good faith for banks in the accountability of bank negligence as well as the importance of customer caution in binding safe deposit box agreements.

Keywords: Bank; Safe Deposit Box; Liability

\section{PENDAHULUAN}

Fungsi lembaga perbankan di Indonesia baik bank nasional maupun bank swasta tidak lagi hanya sebagai lembaga penyimpanan dana namun bankbank tersebut juga berlomba-lomba menawarkan jasa atau pelayanan perbankan kepada masyarakat. Kepercayaan yang diberikan oleh masyarakat merupakan pokok utama dalam menjalankan bisnis perbankan. Manajemen perbankan akan dihadapkan pada berbagai upaya untuk menjaga kepercayaan tersebut agar tetap memperoleh simpati dari calon nasabahnya. Dalam Undang-Undang No. 7 tentang Perbankan, dalam Pasal 6 huruf h, dimana bank 
menyediakan tempat untuk menyimpan barang dan surat berharga.

Menindaklanjuti pasal tersebut bank menawarkan jasa penyewaan Safe Deposit Box (SDB) Bank menyediakan pelayanan penyimpanan dokumen dengan sistem sewa. ${ }^{1}$ Hakikat dari SDB adalah "layanan jasa kotak, atau tempat penyimpanan harta, atau surat-surat berharga, yang memang didesain sedemikian rupa agar kokoh dan tahan api untuk menjaga keamanan barang yang disimpan dan memberikan rasa aman bagi penggunanya." 2

Pembukaan SDB dilakukan dengan dua buah anak kunci, satu kunci dipegang bank dan satu dipegang nasabah, sedangkan pengertian SDB menurut Kasmir adalah "jasa bank yang diberikan khusus kepada para nasabah utamanya. SDB berbentuk kotak dengan ukuran tertentu dan disewakan kepada nasabah yang berkepentingan untuk menyimpan dokumendokumen atau benda-benda berharga miliknya." ${ }^{3}$

Fungsi dari layanan SDB yang dapat ditawarkan oleh Bank kepada nasabah antara lain: Pertama, Sekuritas, yaitu surat berharga dalam bentuk fisik (warkat) yang mempunyai nilai uang yang dapat diperdagangkan di pasar uang dan/atau pasar modal, antara lain sertifikat deposito, saham, atau obligasi; Kedua, Surat yang berharga, yaitu dokumen yang mempunyai nilai bagi penyimpan yang tidak dapat diperdagangkan di pasar uang dan/atau pasar modal, seperti sertifikat tanah, ijazah, akta perkawinan, akta kelahiran, atau dokumen perjanjian; Ketiga, Barang berharga, yaitu berupa uang, baik dalam rupiah maupun valuta asing dan barang yang menurut penilaian penyimpan mempunyai nilai jual tinggi, seperti logam mulia, platina, batu mulia, atau mutiara. $^{4}$

Benda-benda yang dapat disimpan dalam SDB terbatas pada barang-barang atau surat berharga saja, dengan demikian dapat diartikan bahwa sepanjang tidak dilarang oleh bank dan undang-undang maka semua barang dan surat berharga boleh disimpan di dalam SDB. Adapun barang-barang yang tidak boleh disimpan di dalam SDB antara lain seperti senjata

\footnotetext{
${ }^{1}$ Kasmir. (2014). Dasar-Dasar Perbankan Edisi Revisi. Jakarta: PT. Raja Grafindo Persada, h. 182.

2 Djoni S. Gazali dan Rachmadi Usman. (2010). Hukum Perbankan. Jakarta: Sinar Grafika, h. 412.

${ }^{3}$ loc.cit.

${ }^{4}$ loc.cit.
}

api, peledak, narkotika, dan barang-barang yang dianggap berbahaya bagi keamanan negara ataupun khalayak banyak.

Jenis perjanjian yang digunakan dalam penggunaan SDB tersebut adalah perjanjian sewa menyewa oleh karena itu nasabah meletakan seluruh kepercayaannya pada bank untuk menjaga barangbarang berharga milik nasabah. Salah satu jenis perjanjian baku yang tumbuh di masyarakat adalah perjanjian SDB yang memilki arti "jasa penyewaan kotak penyimpanan harta atau surat-surat berharga yang dirancang secara khusus dari bahan baja dan ditempatkan dalam suatu ruang yang kokoh, tahan bongkar dan tahan api untuk memberikan rasa aman bagi penggunanya." 5

Perjanjian sewa menyewa menurut Kitab Undang-Undang Hukum Perdata (selanjutnya disingkat BW) Pasal 1548 adalah "suatu perjanjian dengan mana pihak yang satu mengikatkan dirinya untuk memberikan kepada pihak yang lainnya kenikmatan dari sesuatu barang, selama suatu waktu tertentu dan dengan pembayaran suatu harga yang oleh pihak yang tersebut terakhir itu disanggupi pembayarannya." Perjanjian yang digunakan adalah perjanjian sewa menyewa karena objek yang diatur adalah tetang SDB itu sendiri. Dalam hal ini nasabah menyewa sebuah SDB kepada bank untuk menyimpan barang-barang berharganya.

Harta yang dititpkan oleh penitip kepada bank tidak termasuk harta kekayaan bank, untuk itu harus dibukukan dan dicatat tersendiri. Bank tidak beerhak melakukan pengelaolaan harta titipan milik penitip. Jika bank mengalami kepailitan, harta yang dititipkan harus dikembalikan kepada penitip dalam keadaan utuh. ${ }^{6}$

Bentuk penyimpanan yang dipilih oleh nasabah adalah penyimpanan tertutup dengan alasan barang-barang yang disimpan dalam SDB BII lebih cenderung bersifat pribadi dan rahasia. Atas perjanjian tersebut mengakibatkan munculnya hak dan kewajiban bagi kedua belah pihak. Selain itu ada tanggung jawab hukum jika salah satu pihak

5 Irina Rachmadianty. "Perlindungan Hukum dan Perpektif Ketidakadilan (Unconscionability) Pada Perjanjian Sewa Menyewa SDB”. Malang: Fakultas Hukum Universitas Brawijaya, h. 1.

${ }^{6}$ Endang Retnowati. "Aspek Yuridis Simpanan dan Penitipan Pada Bank”. Jurnal Perspektif. Vol IX No. 4 Edisi Oktober 2004, h. 317. 
melakukan perbuatan melanggar hukum seperti pada kasus nasabah bank BII. "JAKARTA. Dua nasabah Bank International Indonesia (BII) benar-benar kecewa terhadap keamanan fasilitas SDB (SDB) bank itu. Mereka terpaksa menelan kenyataan pahit setelah mengetahui harta benda yang tersimpan di SDB BII hilang. Kedua nasabah itu adalah IS dan IM. IS adalah penyewa SDB nomor D-1579 sedangkan IM menyewa di blok D-1879. Kedua nasabah ini sudah berulangkali mempertanyakan raibnya harta mereka di SDB ke BII. Namun, jawaban BII tak memuaskan mereka."

Setelah kejadian hilangnya barang berharga yang disimpan oleh nasabah dalam SDB, nasabah melakukan gugatan namun pengadilan memutuskan tidak mengabulkan permohonan nasabah sedangkan pencuri yang membobol telah dijatuhi hukuman pidana. Hal ini membuktikan bahwa bank telah lalai dalam melakukan pengawasan terhadap keamanan bank.

Di dalam kasus tersebut nasabah telah menyimpan beberapa barang berharga berupa surat berharga dan perhiasan namun sangat disayangkan sistem pengawasan bank kurang baik sehingga barang-barang yang telah disimpan dalam SDB tersebut dapat dibobol oleh pencuri dengan motif berpura-pura menjadi nasabah. Selain itu kasus serupa juga telah dialami oleh beberapa nasabah yang juga menyimpan harta bendanya di dalam SDB bank BII, namun bank berusaha lepas dari tanggung jawab karena bank tidak mengetahui barang berharga apa saja yang telah disimpan nasabah dalam SDB

\section{PERUMUSAN MASALAH}

Bagaimana tanggung gugat bank terhadap hilangnya barang nasabah yang disimpan dalam SDB?

\section{METODE PENELITIAN}

Metode pendekatan masalah yang digunakan dalam penyusunan penelitian ini adalah melalui pendekatan peraturan perundang-undangan (statute approach), dimana melalui pendekatan ini berusaha untuk membahas ataupun menganalisa sebuah kasus dan menemukan pemecahan sebuah kasus

\footnotetext{
${ }^{7}$ Harta di SDB Raib Nasabah Gugat BII dikutip http:// keuangan.kontan.co.id/news/harta-di-safe-deposit-box-raibnasabah-gugat-bii-tanggal 23/03/2015
}

menggunakan peraturan perundang-undangan yang berlaku.

\section{PEMBAHASAN \\ Perjanjian Safe Deposit Box}

Perjanjian merupakan salah satu sumber lahirnya perikatan menurut Pasal 1313 BW, salah satu atau lebih pihak yang mengikatkan dirinya dalam perjanjian harus memenuhi kewajiban sebagaimana yang dijanjikan dalam suatu perjanjian, dari perjanjian tersebut maka lahirlah perikatan. Pasal 1320 BW menentukan suatu perjanjian baru dapat dikatakan sah apabila memenuhi empat syarat yakni kesepakatan, kecakapan, hal tertentu dan sebab yang halal. Perjanjian yang berlaku di dunia bisnis dapat dibedakan ke dalam perjanjian bernama dan perjanjian tak bernama. Pasal 1319 BW telah menyebutkan adanya kelompok perjanjian, yaitu perjanjian yang oleh undang-undang diberikan suatu nama khusus yang kemudian dapat disebut perjanjian bernama. Contoh perjanjian bernama misalnya perjanjian jual beli dan perjanjian sewa yang namanya disebutkan pula dalam BW. ${ }^{8}$ Perjanjian tidak bernama meliputi perjanjian-perjanjian di luar BW karena nama-nama dari perjanjian tersebut tidak disebutkan dalam BW. Contohnya, perjanjian fidusia dan sewa beli. ${ }^{9}$

Perjanjian Safe Deposit Box (SDB) merupakan sebuah wadah yang digunakan untuk menyimpan barang berhaga dan menghindarkan dari berbagai macam resiko. Salah satu risiko menyimpan dokumen-dokumen penting seperti ijazah, suratsurat berharga, sertipikat tanah atau dokumen lainnya adalah risiko kehilangan atau risiko kerusakan. Risiko hilang karena dicuri atau terselip merupakan risiko utama. ${ }^{10}$ Begitu juga dengan berbagai resiko lainnya seperti bencana alam, kebakaran, banjir dan lain sebagainya.

SDB sangat aman dari pencurian karena untuk membuka SDB harus dilakukan dengan dua buah anak kunci, yaitu kunci unit yang dimiliki oleh nasabah dan bank. Jika salah satu kunci hilang, maka SDB tidak dapat dibuka dan harus dibongkar. ${ }^{11}$

\footnotetext{
${ }^{8}$ J. Satrio. (1992). Hukum Perjanjian. Bandung: Citra Aditya Bakti, h. 115.

${ }^{9}$ ibid., h. 116.

${ }^{10}$ Kasmir. (2014). Dasar-Dasar Perbankan edisi revisi. Jakarta: PT. Raja Grafindo Persada, h. 182.

${ }^{11}$ ibid., h. 183.
} 
Pasal 1548 BW menentukan bahwa yang dimaksud perjanjian sewa menyewa adalah bentuk perjanjian, dimana para pihak saling mengikatkan diri untuk memberikan kepada para pihak kenikmatan dari sesuatu barang, selama waktu tertentu dan dengan pembayaran sesuatu harga, yang oleh pihak tersebut belakangan itu disanggupi pembayarannya. Dari uraian pasal tersebut dapat dianalisis bahwa perjanjian SDB dapat dimasukkan ke dalam perjanjian sewa menyewa karena telah memenuhi beberapa aspek yaitu: bank memberikan kenikmatan berupa penyewaan SDB kepada nasabah sehingga bank mengikatkan dirinya pada nasabah; penyewaan SDB tersebut dilaksanakan dalam tenggang waktu tertentu; dan dalam perjanjian tersebut nasabah memberikan pembayaran kepada bank sebagai suatu imbalan atas jasa yang telah diberikan oleh bank.

Sebagaimana perjanjian yang timbul akibat adanya perikatan antara dua pihak yang saling mengikatkan diri maka muncullah kewajiban dan hak. Di dalam BW kita dapat menemukan beberapa kewajiban yang harus dipenuhi oleh para pihak. Kewajiban penyewa hanyalah sebatas membayar harga sewa pada waktu-waktu yang telah ditentukan menurut perjanjian sedangkan kewajiban pihak yang menyewakan antara lain: Menyerahkan barang yang disewakan kepada si penyewa; Memelihara barang yang disewakan sedemikian hingga itu dapat dipakai untuk keperluan yang dimaksudkan; Memberikan kepada si penyewa kenikmatan tenteram dari barang yang disewakan selama berlangsungnya persewaan. ${ }^{12}$ Setelah melaksanakan kewajibannya barulah kedua belah pihak dapat memperoleh haknya.

Hilangnya barang-barang yang telah dititipkan akibat kelalaian BII menyebabkan BII dapat dikatakan melakukan suatu perbuatan wanprestasi. Sesuai dengan isi Pasal 1243 BW, wanprestasi dapat dibedakan menjadi 4 jenis antara lain: Tidak melakukan apa yang dijanjikan; Melakukan apa yang dijanjikan tetapi terlambat; Melakukan apa yang dijanjikan, tetapi tidak sebagaimana mestinya; atau Melakukan apa yang seharusnya tidak boleh dilakukan berdasarkan perjanjian. ${ }^{13}$

${ }^{12}$ R. Subekti. (1995). Aneka Perjanjian. Bandung: Citra Aditya Bakti, h. 42.

13 Ahmadi Miru. (2012). Hukum Perikatan. Jakarta: RajaGrafindo Persada, h. 8.
Pada kenyataannya BII memang telah berusaha untuk menjaga barang-barang yang dititipkan nasabah di dalam SDB, namun tetap saja BII tidak dapat memenuhi kewajibannya untuk menjaga barang yang sudah disimpan dan dititipkan dalam SDB sampai perjanjian sewa menyewa tersebut berakhir, oleh karena itu BII dapat dikatakan melakukan perbuatan wanprestasi yang tidak memenuhi prestasi sama sekali. Kembali lagi pada ketentuan tentang perikatan untuk berbuat sesuatu yang terdapat dalam Pasal 1239 BW bahwa BII harus melakukan pemenuhan atas kewajibannya, dapat diartikan bahwa BII harus dapat melakukan prestasi secara penuh. Melakukan prestasi secara penuh adalah melakukan segala kewajiban yang telah dibuat dalam perjanjian tanpa terkeculi. Dalam kasus ini BII dikatakan tidak memenuhi prestasi sama sekali karena bank tidak dapat menjaga barang-barang yang telah disimpan dan dititipkan dengan baik sampai perjanjian sewa menyewa SDB tersebut berakhir.

Dalam kasus ini BII telah melakukan beberapa kelalaian yang berakibat fatal antara lain:

Pertama, kelalaian yang pertama BII lalai dalam pelaksanaan pengawasaan keamanan sehingga para perampok yang telah memalsukan identitasnya dapat masuk ke ruang SDB dengan leluasa.

Kedua, BII tidak menyediakan kamar khusus untuk memasukan dan/atau mengambil barang, selain itu mutu dari SDB yang digunakan oleh BII kualitasnya buruk sehingga dapat dicongkel dengan mudah.

Ketiga, dalam ruangan SDB tidak ada CCTV (closed circuit television) dengan tidak adanya CCTV dalam ruangan SDB, perampok akan lebih leluasa untuk membobol SDB yang diinginkan. ${ }^{14}$

Kasus pembobolan SDB sebelumnya juga sudah pernah terjadi dan dialami oleh nasabah BII lainnya namun tetap saja tidak ada itikad baik dari BII untuk memberikan ganti rugi, selain itu pelaku pembobolan dalam kasus SDB IM sudah tertangkap dan dipidanakan.

Menurut Abdulkadir Muhamad: "Dalam pembuatan suatu perjanjian memang diperbolehkan membuat suatu perjanjian tentang peralihan tanggung jawab memikul beban baik berupa biaya maupun kerugian yang mungkin timbul. Dalam Ketentuan

\footnotetext{
${ }^{14}$ Putusan Kasasi Nomor 897K/Pdt/2011, h. 19-30.
} 
khusus ini disebut klausula eksonerasi," 15 tetapi dalam pembuatan klausula tersebut tidak dapat dibenarkan jika perjanjian yang dibuat hanya untuk menguntungkan salah satu pihak di kemudian hari. Sejatinya klausula baku tersebut digunakan oleh pengusaha untuk suatu tujuan tertentu antara lain: Efisiensi biaya, waktu, dan tenaga; Praktis karena sudah tersedia naskah yang dietak berupa formulir atau blanko yang siap diisi dan ditandatangani; Penyelesaian cepat karena konsumen hanya menyetujui dan atau menandatangani perjanjian yang disodorkan kepadanya; dan Homogenitas perjanjian yang dibuat dalam jumah yang banyak. ${ }^{16}$

Banyaknya jumlah pasal yang terdapat pada Perjanjian SDB format baku serta terbatasnya pengetahuan nasabah terhadap aspek hukum perjanjian sangat mungkin untuk menyebabkan nasabah tidak mampu membaca secara cermat untuk benar-benar memahami isi perjanjian sehingga pada akhirnya nasabah cenderung akan langsung menyetujui saja apa yang ditetapkan oleh bank tanpa bertanya lebih lanjut tentang penjelasan di dalam setiap pasalnya. Pada umumnya perjanjian dibuat berdasarkan kesepakatan para pihak namun seiring dengan perkembangan binis di masyarakat, perjanjian ditetapkan oleh pelaku usaha terlebih dahulu dan dituangkan ke dalam sebuah form perjanjian dimana form tersebut diberikan kepada konsumen (nasabah) untuk dibaca. Perjanjian dianggap sah setelah nasabah membubuhkan tandatangannya meskipun ia telah benar-benar membacanya ataupun tidak, nasabah dianggap telah diberi kesempatan untuk membaca dan memahami isi perjanjian. Oleh sebab itu, tentu perlu adanya itikad baik dari bank sejak tahapan pra perjanjian untuk menanyakan apakah nasabah sudah benar-benar jelas dengan isi perjanjian tersebut sebagai bentuk profesionalitasnya. Klausula eksonorasi seharusnya hanya boleh dilaksanakan oleh pelaku usaha yang memiliki itikad baik saja.

Syarat-syarat yang dimuat dalam suatu perjanjian perjanjian yang merupakan pernyataan persetujuan, dapat ditentukan sendiri secara sepihak oleh pengusaha atau organisasi pengusaha. Karena syarat-syarat perjanjian itu dibuat oleh pengusaha, maka sifatnya

\footnotetext{
${ }^{15}$ Abdulkadir Muhammad. (1992). Perjanjian Baku dalam Praktek Usaha Perdagangan. Bandung: Citra Aditya Bakti, h. 83.

${ }^{16}$ ibid., h. 8-9.
}

cenderung lebih menguntungkan pengusaha daripada konsumen. Hal ini terlihat jelas dalam klausula eksonerasi yang berupa pembebasan tanggung jawab pengusaha, tanggung jawab tersebut menjadi beban konsumen. Pembuktian oleh pihak pengusaha yang membebaskan diri dari tanggung jawab sulit diterima oleh konsumen karena ketidak-tahuannya. Perjanjian yang diberikan kepada konsumen dibuat dengan syarat sepihak oleh pengusaha dimana konsumen dihadapkan pilihan, jika setuju dengan perjanjian tersebut maka konsumen dapat menandatangani perjanjian tersebut beserta seluruh konsekuensinya atau menolak perjanjian tersebut. Apabila konsumen bersedia menerima syarat-syarat perjanjian yang ada maka konsumen dapat menandatangani perjanjian tersebut. Penandatanganan tersebut menunjukkan bahwa konsumen bersedia memenuhi segala bentuk tanggung jawab walaupun mungkin ia tidak bersalah. Jika konsumen tidak setuju dengan syarat-syarat perjanjian yang diberikan itu, maka konsumen tidak boleh menawar syarat-syarat yang sudah dibakukan itu. Menawar syarat-syarat baku berarti menolak perjanjian. ${ }^{17}$

Untuk tujuan tertentu seperti kepraktisan di antara para pihak maka dipergunakanlah klausula eksonerasi oleh pelaku usaha, karena memerlukan waktu dan proses yang cukup panjang bagi bank jika harus bernegosiasi satu persatu dengan seluruh nasabah mengenai isi dari suatu perjanjian yang hendak disepakati bersama. Kondisi ini memungkinkan bank untuk memanfaatkan keadaan dengan membuat klausula-klausula yang membebankan nasabah sehingga terjadi ketidakseimbangan posisi di antara para pihak dimana bank sebagai penyedia jasa layanan SDB berada dalam posisi yang dominan sedangkan nasabah yang memerlukan jasa tersebut seolah-olah terpaksa untuk menandatangani perjanjian tersebut.

Pasal 18 ayat (1) huruf a UUPK menentukan agar pelaku usaha dalam menawarkan barang dan/ atau jasa yang ditujukan untuk diperdagangkan dilarang membuat atau mencantumkan klausula baku pada setiap dokumen dan/atau perjanjian apabila menyatakan pengalihan tanggung jawab pelaku usaha. Secara jelas sudah ditentukan bahwa bank tidak boleh menyatakan pengalihan tanggung jawab, dalam kasus inipun sebenarnya BII sudah tidak bisa mengelak untuk memberikan ganti rugi kepada

17 ibid., h. 7-8. 
nasabah yang dirugikan karena dengan bukti-bukti yang ada mengarahkan pada kelalaian yang dilakukan bank. BII juga tidak berada dalam keadaan memaksa yang memungkinkan bank lepas dari tanggung jawab. Tanggung jawab untuk mengembalikan harta dan benda berharga yang hilang ke dalam kondisi semula ada pada BII, karena BII telah melakukan kesalahan. Pihak yang melakukan kesalahan tidak boleh mendapatkan keuntungan dari perjanjian dan pihak yang tidak melakukan kesalahan tidak boleh dirugikan akibat perjanjian tersebut. Setiap klausula baku yang telah ditetapkan oleh pelaku usaha pada dokumen atau perjanjian yang memenuhi ketentuan sebagaimana dimaksud pada Pasal 18 ayat (1) dinyatakan batal demi hukum, oleh sebab itu BII dengan itikad baik seharusnya bertanggung jawab dengan cara memberi ganti rugi terhadap nasabah yang telah dirugikan atas hilangnya barang-barang yang telah disimpan di dalam SDB BII. Setidaknya senilai dengan jumlah harga barang yang hilang.

Itikad baik adalah suatu pengertian mengenai apa yang berada di dalam pikiran manusia di dalam menentukan suatu sikap yang dilandasi dengan suatu nilai kepatutan yang berada di masyarakat dan pada penilaian intrinsik yaitu penilaian yang berasal dari hati nurani. Penyusunan perjanjian sejak awal harus dilandasi dengan itikad baik bank di dalam merumuskan isi perjanjian baku tersebut hingga dalam tahap pelaksanaan perjanjian dan pasca pelaksanaan perjanjian. Bank sebagai lembaga kepercayaan seharusnya memikirkan dampak jika beritikad tidak baik karena sekali nama baik bank tersebut tercoreng maka dengan sendirinya nasabah yang bersangkutan akan meragukan kredibilitas bank tersebut sehingga ada kemungkinan untuk berpindah ke bank yang dianggap memiliki kredibilitas yang lebih baik.

J. Satrio membedakan itikad baik menjadi dua yaitu itikad baik subjektif dan objektif. "Iktikad baik subjektif (subjectief goeder trouw), yaitu apakah yang bersangkutan sendiri menyadari, bahwa tindakannya bertentangan dengan iktikad baik, sedang iktikad baik objektif (objectief goeder trouw) adalah, kalau pendapat umum (jadi objectief) menganggap tindakan yang begitu adalah bertentangan dengan iktikad baik."18 Etika bisnis yang baik juga harus

18 J. Satrio. (1992). Hukum Perjanjian. Bandung: Citra Aditya Bakti, h. 379. diterapkan bersamaan dengan itikad baik pelaku usaha. Bisnis harus berlaku etis demi kepentingan bisnis itu sendiri. ${ }^{19}$ Pelaku usaha tidak seharusnya berbuat curang demi mendapatkan keuntungan, dengan menerapkan itikad baik dan menjaga etika bisnis yang baik pelaku usaha bisa tetap mendapatkan keuntungan dan tidak ada pihak-pihak yang merasa dirugikan.

\section{Tanggug Jawab BII dalam Hilangnya Obyek Perjanjian Safe Deposit Box}

Akibat dari tidak terpenuhinya prestasi yang merupakan kewajiban dari BII maka BII harus bertanggungjawab atas kerugian yang timbul kepada nasabah. Tanggung jawab dapat dibedakan menjadi dua yaitu tanggung jawab profesional dan tanggung jawab hukum.

\section{Pertama, Tanggung jawab profesional lembaga}

Dalam menjalankan bisnis perbankan, bank sebagai salah satu lembaga kepercayaan masyarakat harus dapat memberikan layanan yang profesional dan terbaik kepada nasabah, pelayanan yang profesional meliputi penerapan prinsip kehatihatian dalam menyimpan harta masyarakat karena bank merupakan lembaga kepercayaan masyarakat, selain itu bank juga harus memberikan penjelasan secara detil tentang layanan yang diberikan kepada masyarakat namun dalam hal ini ternyata terbukti bank tidak bekerja secara profesional sehingga nasabah merasa dirugikan atas hilangnya harta dan barang berharga yang telah disimpan dan dititipkan dalam SDB BII, mengingat lokasi SDB tersebut ada dalam jangkauan pengawasan BII.

Ketidakprofesionalan BII dalam hal ini adalah tidak menerapkan prinsip kehati-hatian dalam mencocokan data yang dimiliki bank dengan kartu identitas yang dimiliki nasabah. Ketidakprofesionalan bank dapat berakibat buruk bagi bank itu sendiri karena bank dalam kasus ini menawarkan dan bertindak sebagai penasihat agar nasabah mau menyimpan harta dan barang berharganya di BII dengan menyepakati Perjanjian Sewa Menyewa SDB. Untuk menciptakan dan membina hubungan jangka panjang yang saling menguntungkan bank

19 Lanny Kusumawati. (2010). Aspek Hukum dalam Persaingan Usaha. Sidoarjo: Laros, h. 232. 
seharusnya memberikan pelayanan secara profesional dan pribadi kepada nasabah.

Kehati-hatian berasal dari kata "hati-hati" (prudent) yang erat kaitannya dengan fungsi pengawasan bank dan manajemen bank. "Prudent dapat juga diterjemahkan dengan bijaksana, namun dalam dunia perbankan istilah itu digunakan dan diterjemahkan dengan hati-hati atau kehati-hatian (prudential). ${ }^{20}$

Prinsip kehati-hatian mewajibkan pihak Bank untuk selalu teliti dalam menjalankan usaha, serta konsisten dalam melaksanakan peraturan dibidang perbankan berdasarkan profesionalisme dan itikad baik. Peraturan prinsip kehati-hatian dalam perbankan meliputi pelayanan jasa-jasa perbankan maupun dalam hal pengumpulan dan penyaluran dana kepada masyarakat. Prinsip kehati-hatian (prudential principle) dalam sistem perbankan digunakan sebagai antisipasi terhadap risiko atau terhadap keadaan-keadaan yang tidak diinginkan.

\section{Kedua, Tanggung jawab hukum}

Ada tiga hal yang harus dipertanggungjawabkan oleh BII antara lain tanggung jawab secara perdata, tanggung jawab secara administrasi, tanggung jawab secara pidana.

\section{a. Tanggung Jawab Perdata}

Pasal 1243 BW: Penggantian biaya, rugi, dan bunga karena tidak dipenuhinya suatu perikatan, barulah mulai diwajibkan apabila debitur, setelah dinyatakan lalai memenuhi perikatannya, atau jika sesuatu yang harus diberikan atau dibuatnya hanya dapat diberikan atau dibuat dalam tenggang waktu yang dilampaukannya.

Pasal 19 ayat (1) UUPK: Pelaku usaha bertanggung jawab memberikan ganti rugi atas kerusakan, pencemaran, dan/atau kerugian konsumen akibat mengkonsumsi barang dan/atau jasa yang dihasilkan atau diperdagangkan.

Berdasarkan kedua pasal tersebut maka BII telah memenuhi unsur untuk memberi ganti rugi kepada nasabah. Pertama, karena bank telah lalai dalam menerapkan prinsip kehati-hatian dalam mencocokan data nasabah pemilik SDB sehingga orang lain yang tidak bertanggung jawab dapat masuk dengan mudah dan membobol barang berharga milik nasabah

20 Permadi Gandapraja. (2004). Dasar dan Prinsip Pengawasan Bank. Jakarta: Gramedia Pustaka Utama, h. 21. pemilik SDB yang sebenarnya, atas kelalaian tersebut BII harus bertanggung jawab.

Kedua, nasabah setelah menggunakan jasa layanan SDB BII mengalami kerugian material. Nasabah menggunakan jasa layanan SDB untuk menyimpan harta benda dan barang berharga seperti sertipikat dan perhiasan yang bernilai ratusan juta, namun setelah disimpan dalam SDB BII, harta benda dan barang berharga yang disimpan nasabah justru hilang tidak diketahui keberadaannya.

Jika dikaitkan dengan perjanjian baku, dapat diketahui bahwa antara pelaku usaha yang menjual barang dan/atau jasanya terdapat suatu hubungan hukum, yang demi hukum terhitung pada saat dilaksanakannya transaksi jual/beli barang dan/atau jasa tersebut. Dengan demikian setiap pelanggaran yang dilakukan oleh pelaku usaha yang menyebabkan kerugian kepada pembeli merupakan pelanggaran atas prestasi pelaku usaha yang telah diperjanjikan sebelumnya kepada pembeli. Dalam hal ini pembeli berhak untuk "menuntut pembatalan perjanjian (tergantung pada jenis transaksi perdagangan barang dan/atau jasa yang dilaksanakan) serta meminta penggantian segala macam biaya dan bunga berikut kerugian aktual yang diderita konsumen." ${ }^{21}$

b. Tanggung Jawab Administrasi

Tanggung jawab administrasi dalam hal ini bukan diartikan dalam lingkup hukum tata negara melainkan proses pendataan yang bersifat administratif yang dilakukan oleh bank.

Berikut tata cara pembukaan SDB:

Pertama, Nasabah datang ke bank dan menemui petugas untuk menyerahkan kartu anggota dan KTP.

Kedua, Petugas SDB mencocokan kartu anggota dan KTP dengan data nasabah yang ada pada arsip bank.

Ketiga, Setelah diperiksa petugas SDB dan data terebut sesuai maka petugas memberikan form registrasi yang berisi: Tanggal kedatangan, Jam masuk ke ruang SDB; Jam keluar dari ruang SDB.

Keempat, Nasabah didampingi oleh petugas SDB sebanyak satu orang masuk ke ruang SDB untuk membuka pintu SDB secara bersama-sama, jika ada nasabah lain di ruang tersebut maka harus menunggu nasabah yang terlebih dulu ada di ruangan selesai dan keluar dari ruangan karena pada saat membuka SDB

${ }^{21}$ Gunawan Wijaja. (2003). Hukum tentang Perlindungan Konsumen. Jakarta: Gramedia Pustaka Utama, h. 63-64. 
yang berhak berada di ruang tersebut hanya nasabah dan petugas SDB.

Kelima, Setelah pintu SDB dibuka bersama-sama oleh nasabah dan petugas SDB, kemudian petugas SDB meninggalkan nasabah di ruang SDB sendirian.

Keenam, Nasabah diberi waktu 15 menit untuk berada di ruang SDB, jika lebih dari 15 menit nasabah tidak meninggalkan ruang SDB maka petugas SDB mengetok pintu ruang SDB untuk menandakan waktu di dalam ruang SDB telah habis.

Ketujuh, Nasabah selama 15 menit bebas di ruangan yang berisikan SDB-SDB tersebut tanpa diketahui apa yang sesungguhnya diperbuat oleh nasabah tersebut.

Kedelapan, Nasabah dapat mengunci pintu SDB tanpa didampingi petugas SDB lalu nasabah keluar dari ruang SDB.

Kewajiban administratif BII adalah harus mendata secara akurat setiap nasabah yang keluar dan masuk ruang SDB, tidak hanya nasabah namun juga staf yang bertugas melayani pembukaan ruang SDB karena sebagaimana yang diketahui bahwa staf adalah orang yang menjaga dan orang yang mempunyai akses paling luas untuk masuk ke dalam ruangan SDB tersebut. Berdasarkan keleluasaan tersebut, staf yang mempunyai itikad tidak baik dapat dimungkinkan melakukan persekongkolan dengan orang lain yang tidak bertanggungjawab untuk membobol SDB tersebut.

Bank harus teliti dalam mencocokan data tentang identitas nasabah yang dimiliki oleh bank dengan kartu tanda pengenal (KTP) yang dimiliki nasabah sehingga kecil kemungkinan untuk orang lain yang telah memalsukan identitas dan hendak masuk ke ruangan tersebut dapat lolos dari penjagaan staf BII. Atas pelanggaran tersebut BII dapat dikenakan sanksi berupa denda, bunga, atau pencabutan izin usaha.

c. Tanggung Jawab Pidana

Tanggung jawab pidana dilakukan sebagai upaya terakhir yang dapat ditempuh oleh nasabah jika bank tetap tidak mau bertanggung jawab secara perdata maupun administrasi kepada nasabah. Nasabah dapat melaporkan tindak pidana pencurian atas harta dan benda berharga, dalam hal ini BII dapat memberi keterangan kepada polisi karena hilangnya barangbarang tersebut berada dalam lokasi pengawasaan BII. Tertangkapnya pencuri oleh pihak kepolisian membuktikan bahwa BII telah lalai dalam melakukan pengawasan, oleh sebab itu BII harus memberikan ganti rugi kepada nasabah.

\section{PENUTUP \\ Kesimpulan}

Hilangnya harta dan barang berharga nasabah yang disimpan dalam SDB BII menunjukkan bahwa BII telah melakukan perbuatan wanprestasi sehingga bank harus meberikan ganti rugi berdasarkan Pasal 1243 BW. Perjanjian Sewa Menyewa SDB yang menyatakan bahwa bank tidak bertanggung jawab atas hilangnya barang kecuali dapat dibuktikan sebaliknya bahwa hal tersebut terjadi akibat kesalahan dan/atau kelalaian bank, tidak dapat digunakan oleh bank untuk lepas dari tanggung jawab karena bank terbukti telah lalai di dalam pengawasannya sehingga ada orang lain yang bukan nasabah dapat membobol SDB.

\section{Rekomendasi}

Bank sebagai pelaku usaha harus memiliki itikad baik dalam menjalankan usahanya. Itikad baik sejatinya suatu hal yang bersifat moril namun karena banyak pelaku usaha yang tidak mengindahkan hal tersebut maka dibuatlah suatu perundang-undangan. Pasal 7 huruf a UUPK menetapkan, kewajiban pelaku usaha adalah beritikad baik dalam melakukan kegiatan usahanya. Dalam hal ini bank sebagai lembaga kepercayaan tidak boleh lepas dari tanggung jawab apalagi jika sudah terbukti lalai.

Nasabah hendaknya juga meneliti isi perjanjian sebelum menyetujui perjanjian tersebut, nasabah harus bertanya kepada bank jika ada suatu klausul yang dianggap kurang jelas sehingga tidak menimbulkan penafsiran yang berbeda antara nasabah dan bank. Nasabah juga harus bisa bijaksana dalam menyikapi tawaran atas suatu jasa yang diberikan oleh bank, nasabah tidak boleh mudah tergiur dengan tawarantawaran yang diberikan oleh bank agar nasabah tidak menyesal di kemudian hari.

\section{DAFTAR PUSTAKA}

\section{Peraturan Perundang-undangan:}

Kitab Undang-Undang Hukum Perdata.

Undang-Undang No. 10 Tahun 1998 tentang Perubahan atas Undang-Undang Nomor 7 Tahun 1992 tentang Perbankan. 


\section{Buku:}

Abdulkadir Muhammad. (1992). Perjanjian Baku dalam Praktek Usaha Perdagangan. Bandung: Citra Aditya Bakti.

Ahmadi Miru. (2012). Hukum Perikatan. Jakarta: RajaGrafindo Persada.

Djoni S. Gazali dan Rachmadi Usman. (2010). Hukum Perbankan. Jakarta: Sinar Grafika.

Gunawan Wijaja. (2003). Hukum tentang Perlindungan Konsumen. Jakarta: Gramedia Pustaka Utama.

Irina Rachmadianty. "Perlindungan Hukum dan Perpektif Ketidakadilan (Unconscionability) Pada Perjanjian Sewa Menyewa SDB". Malang: Fakultas Hukum Universitas Brawijaya.

J. Satrio. (1992). Hukum Perjanjian. Bandung: Citra Aditya Bakti.

Kasmir. (2014). Dasar-Dasar Perbankan Edisi Revisi. Jakarta: PT. Raja Grafindo Persada.

Lanny Kusumawati. (2010). Aspek Hukum dalam Persaingan Usaha. Sidoarjo: Laros.
Permadi Gandapraja. (2004). Dasar dan Prinsip Pengawasan Bank. Jakarta: Gramedia Pustaka Utama.

R. Subekti. (1995). Aneka Perjanjian. Bandung: Citra Aditya Bakti.

\section{Jurnal:}

Endang Retnowati. "Aspek Yuridis Simpanan dan Penitipan Pada Bank". Jurnal Perspektif. Vol IX No. 4 Edisi Oktober 2004.

\section{Website:}

Harta di SDB Raib Nasabah Gugat BII dikutip dari http://keuangan.kontan.co.id/news/hartadi-safe-deposit-box-raib-nasabah-gugat-biitanggal 23/03/2015

\section{Lainnya:}

Putusan Kasasi Nomor 897K/Pdt/2011. 